\title{
Number and Nest-Site Selection of Breeding Black- Necked Cranes Over the Past 40 Years in the Longbao Wetland Nature Reserve, Qinghai, China
}

\section{Qiufang Wei}

Aerospace information research institute, Chinese academy of sciences

\section{Yun Shao}

Chinese Academy of Sciences Aerospace Information Research Institute

Chou Xie ( $\nabla$ xiechou@aircas.ac.cn )

AIR: Chinese Academy of Sciences Aerospace Information Research Institute

\section{Baoshan Cui}

Beijing Normal University School of Environment

\section{Bangsen Tian}

Chinese Academy of Sciences Aerospace Information Research Institute

\section{Brian Brisco}

Natural Resources Canada

Kun Li

Chinese Academy of Sciences Aerospace Information Research Institute

\section{Wenjia Tang}

Qinghai eco-environment monitoring center

\section{Research Article}

Keywords: Black-necked crane, Longbao wetland, Number, Nest site selection, Climate change, Human activities

Posted Date: February 9th, 2021

DOl: https://doi.org/10.21203/rs.3.rs-160521/v1

License: (c) (i) This work is licensed under a Creative Commons Attribution 4.0 International License. Read Full License 


\section{Abstract}

Black-necked crane (Grus nigricollis, BNC) is an endangered species classified as vulnerable under the revised IUCN Red List, and it faces serious threats from human activities and habitat variations. We investigated and analyzed the population and nesting microhabitat of BNCs in the Longbao National Nature Reserve (NNR) from 1978 to 2016. The number average growth rate of each decade was different, and we analyzed the reasons for the number increase from several aspects, including land cover and climate change. The establishment of the Longbao NNR represented an effective method of protecting endangered animal species. However, the land cover classification results of Landsat images showed that the marsh wetland, which is the BNC's primary habitat, decreased, while artificial buildings, including roads and houses, increased, which affected the habitat of BNCs. The average temperature increase over the past 40 years has also had an impact on the number of BNCs. We observed 9 BNC nests, which included 5 island nests and 4 grass nests, by telescope in 2018. BNCs prefer to nest in swampy wetlands or on islands with open water or star-like distributions. The results of the principal component analysis showed that among the six microhabitat factors (elevation, habitat type, distance to roads, shortest distances to nearest water body, nearest distance between nests and disturbance), the nearest distance between nests and habitat type were the primary factors influencing nesting site selection. To promote this species, we suggest decreasing wetland fragmentation, reducing habitat degradation and providing an undisturbed habitat.

\section{Introduction}

Black-necked crane (BNC, Grus nigricollis) is the only one of the world's 15 crane species that breeds completely in the high-altitude freshwater wetlands of the Qinghai-Tibetan Plateau (Bishop 1996; Li and Bishop 1999; Li et al. 2005). The global population of this species increased from 5600-6000 to 1000011000 from the 1990s to the present (Bishop 1996; Bishop and Tsamchu 2007; Harris and Mirande 2013; Li 2014). Since 1994, it has been classified as vulnerable under the revised International Union for Conservation of Nature Red List (BirdLife International, 2017) due to its single small population, widespread wetland degradation and human activities (Farrington and Zhang 2013; Harris and Mirande 2013; Wu et al. 2013). Quantitative statistical information and habitat selection data play a guiding role in the formulation of species protection plans. Therefore, it is vital and important to investigate and analyze the number and nest-site selection for BNCs.

Breeding populations are widely distributed in China, including Qinghai, Tibet, Sichuan, Gansu and Xinjiang Provinces (Bishop 1996; Li et al. 2005), and the largest and densest known concentrations occur in three areas: (1) the Ruoergai marsh in northern Sichuan Province, with an estimated BNC population of 2635 (Scott 1993; Li 2014; Liu et al. 2014); (2) Shenzha County and the Seling Lake BNC National Nature Reserve in central Tibet (no accurate population estimate available) (Dwyer et al. 1992); and (3) the Longbao National Nature Reserve (NNR) in southern Qinghai, with approximately 216 according to the latest records (Bishop 1996; Farrington and Zhang 2013). Most research on the number of BNCs has focused on Ruoergai (Zhang and Luo 1991; Du et al. 2013; Liu et al. 2014; Jiang et al. 2017) and Tibet 
(Dwyer et al. 1992; Cangjue et al. 2008). Earlier studies focused on Longbao, although the number is limited. In the 1980s, several scientists investigated the population numbers, geographical distribution, habitat characteristics and other ecological problems of BNC in Longbao (Guo JT 1981; Yao JC 1982; Li DH and Zhou ZJ 1985). Recently, only Farrington and Zhang surveyed this area and counted the population numbers (Farrington and Zhang 2013). Researchers usually use binoculars or spotting scopes to survey areas and count the number of animals. However, studies performing qualitative influence factor analyses (such as wetland variation and climate change) on the number of BNCs are deficient. Only Ma researched the dynamic change in the ecological environment in the Longbao region (2009).

Understanding nest site selection characteristics is imperative for making conservation decisions on bird habitats, and managers usually lack such knowledge (Bock 1997, Caughley 1994, Willson and Gende 2000, Wu et al. 2009). Many studies have indicated that the breeding sites of BNC are concentrated in plateau meadows, swampy meadows and marshes, where herbaceous plants are abundant (Zhang and Luo 1991; Dwyer et al. 1992; Kuang et al. 2010; Song et al. 2014). According to some early surveys, the BNCs in Longbao prefer to nest in alpine meadows and marshlands with shallow water that are difficult for people to enter (Lü ZB et al. 1980; Guo JT. 1981; Wang YH et al. 1989). Wang and Chen (2002) classified BNC nests into five types: island nests, mud nests, reed nests, grassy island nests, and temporary nests. Most of the nests in Longbao are island nests, and some are grass nests. Wu (2009) performed a principal component analysis (PCA) and found that the factors associated with the selection of nest sites in the Ruoergai wetland included water body size, distance to water, water depth and nest concealment level. Another study performed a factor analysis and found that nest site selection by BNC in the Yanchiwan National Nature Reserve was determined by habitat type, disturbance and water depth (Zhang and An 2017). Other researchers (Dwyer and Bishop 1992) collected nest-site data in the Tibetan autonomous region, including altitude, height above water, distance to upland and distance to disturbance. Recently, Farrington and Zhang located 29 BNC nests within the main Longbao wetland in the spring of 2011 (Farrington and Zhang 2013), although the characteristics underlying the selection of nesting environment, such as the water area, vegetation area and interference condition, were not analyzed. Obtain all the nest site characteristics through observations is difficult, especially for certain nest locations that may be surrounded by water or marsh that investigators could not obtain. Compared with on-site observations, abundant nesting information can be efficiently obtained through satellite images.

Plateau wetlands provide indispensable habitats for BNCs. The dynamic changes in plateau wetlands caused by climate fluctuations and human disturbance directly influences the microhabitats and biological behaviors of BNC. Therefore, in this study, we selected the Longbao NNR as a case study to (1) collect the number of BNCs in Longbao NNR since 1978; (2) analyze the nest site selection characteristics of BNCs in Longbao wetland; and (3) analyze the influence of land cover and climate change on the $\mathrm{BNCs}$. We hope to provide a reference for decision-making regarding the protection of BNCs in the Longbao NNR wetland. 


\section{Study Area}

The Longbao National Nature Reserve (NNR, 33.11 $\sim 33.27^{\circ} \mathrm{N}, 96.39^{\circ} \sim 96.69^{\circ} \mathrm{E}$ ), which is located in Longbao Town of Yushu County, Qinghai Province, has an area of approximately $100 \mathrm{~km}^{2}$ and an elevation of approximately $4100 \sim 4200 \mathrm{~m}$. It was established as the first NNR in 1986 to protect BNCs and its habitats in Qinghai Province. The reserve is approximately $14 \mathrm{~km}$ long and has a maximum width of approximately $3.5 \mathrm{~km}$ and a maximum depth of approximately $4 \mathrm{~m}$ (Fig. 1). The Longbao Lake basin is a permanent freshwater lake surrounded by mountains on three sides. The wetland is fed by groundwater, streams, precipitation, and snowmelt. It finally flows into the Tongtian River, which is the main body of the Yangtze River. The wetland is a typical swampy meadow and alpine meadow area that provides sufficient food and a good ecological environment for waterfowl migratory birds. It is reputed as "the hometown of BNCs" by bird experts around the world.

The Longbao Lake basin has a typical plateau continental climate that varies significantly during the four seasons. Under the control of the Qinghai-Tibet high pressure, windy, dry and cold conditions occur in winter. However, under the influence of hot and low pressure and the southwest monsoon, rainy and humid occur in summer. Because of the high altitude, the air is thin and the growth period of vegetation is short.

The entire Longbao NNR is grazed by livestock. Approximately 671 households with a population of 3263 people reside in the northwest of the reserve. The total number of livestock exceeds 28000 . Large tracts of the main wetland have been divided into individual household pasture allotments, and since 1997, these single-family allotments have been fenced off. A trunk road (S308) linking Yushu and Zhiduo County was built through the reserve periphery. Animal husbandry is the leading industry and the main source of local finance.

BNCs likely arrive at Longbao at the end of March from wintering areas and depart at the end of October each year. Crane pairs prefer to nest in mounds (or small islands) in shallow-water wetlands with low vegetation and use the deep mud layers near their nest to escape from predators or to prevent the nest from being flooded. They feed mainly on wetland plants and some small animals, such as fish and shrimp. BNCs usually breed one nest and lay 1-2 eggs at the end of April to mid-June annually. After incubation for 31-33 days, the chicks break out from early June to mid-July.

\section{Data And Methods}

\section{Collecting BNC numbers}

As the Longbao wetland is located in the remote hinterland of the plateau, observations about BNC and its habitats in Longbao are lacking or scarce. Few BNCs were observed before the establishment of the reserve. After the reserve was proposed in 1986, early statistics on the BNC population were not entirely 
accurate because of the difficult conditions of the reserve. Therefore, we collected the number of BNCs for 1986-2016 from the Longbao NNR and related literature.

\section{Nest sites observation and microhabitats analysis}

Farrington et al. (2013) observed 29 BNC nest locations in the main Longbao wetland on May 27, 2011 (Fig. 2(a)). We also surveyed the roosting sites in the study area from May 29 to June 1 in 2018. The nesting locations are mainly in the swamp area, which is difficult to reach. We used binoculars to observe the nesting environment of BNCs. The geographic position of the observation point and the azimuth of the nest site were recorded. We also measured the distance between the BNC nests and observation points through visual measurements. We observed 9 BNC nests in 2018 (Fig. 2(b)).

According to the nesting environment, the following six site characteristics were recorded to determine their influence on nest-site selection: elevation $(m)$, habitat type (lake island, marsh meadow or alpine meadow), distance to roads (far $\otimes 1000 \mathrm{~m}$ and close $\otimes 1000 \mathrm{~m}$ ), shortest distance to nearest water body, nearest distance between nests, and disturbances (high: livestock, humans or dogs can approach the nest; or minor: livestock cannot approach the nest site due to a water barrier). ArcGIS software was used to locate the observation points on remote sensing images, and we measured the nesting microhabitat factors, including elevation, distance to roads, shortest distance to nearest water body and the nearest distance between nests. We obtained the six site factors of the 29 nesting locations observed by Farrington et al. (2013) on May 27, 2011, through DEM and Landsat satellite images. Then, PCA method was used to examine the influence degree of each factor.

\section{Land cover change in the reserve}

The BNCs mainly inhabit the core marsh area in the Longbao wetland. The land cover variation in the Longbao wetland represents the change in habitat for BNC. We selected and classified two Landsat images that covered the Longbao wetland with abundant rainfall and lush vegetation. Then, the changes in the ecological environment in the Longbao wetland since the establishment of the NNR were analyzed. The whole Longbao NNR is divided into a core area, buffer zone and experimental area (Fig. 3), and the edge of the experimental area just overlaps with the Zhiduo highway. To comprehensively analyze the environmental changes throughout the whole area, we used the edge of the protected area as a $1 \mathrm{~km}$ external buffer for the study area. Through field observations and investigations in 2018, the study areas were divided into eight categories: roads, rivers, lakes, buildings, alpine tundra, alpine meadow, marsh meadow and bare land. We interpreted roads and rivers first as long and thin. Then, we selected the training samples and classified them by the support vector machine algorithm in ENVI.

\section{Climate change and statistical analysis}

Climate change affects the reproduction of BNCs and vegetation growth in the Longbao wetland. The meteorological data from 1986 to 2016 for Yushu station were obtained from the China meteorological 
data network, including the 20-20 hour daily precipitation and mean temperature. Then, we analyzed the change trend of meteorological factors at Yushu station.

\section{Results}

BNC numbers

Table 1 Summary of known BNC counts at Longbao wetland

\begin{tabular}{|c|c|c|c|c|c|}
\hline Data sources & Decade & Year & Adult BNC & Chicks & Total \\
\hline Yao (1982) & \multirow[t]{3}{*}{$1980 \mathrm{~s}$} & 1978.6 & & & 24 \\
\hline Li and Zhou (1985) & & 1984.7-8 & 24 & 5 & 29 \\
\hline Li and Ma (1989) & & 1988.5 & 28 & & 28 \\
\hline Lin Z (2006) & \multirow[t]{5}{*}{$1990 \mathrm{~s}$} & 1991 & 64 & & 64 \\
\hline Website (1992) & & 1992 & & & 117 \\
\hline Wong (2002) & & 1996.5 & $75-80$ & & $75-80$ \\
\hline Li (2002) & & 1998.7 & & & 108 \\
\hline Forestry Bureau & & 1999 & & & 117 \\
\hline Website & \multirow[t]{4}{*}{$2000 s$} & 2002 & & & 158 \\
\hline Forestry Bureau & & 2004 & & & 124 \\
\hline Longbao NNR & & 2006 & & & 150 \\
\hline Forestry Bureau & & 2009 & & & 158 \\
\hline John (2013) & \multirow[t]{6}{*}{$2010 s$} & 2010.10 .28 & $<112$ & $>6$ & 118 \\
\hline John (2013) & & 2011.4 & & & 216 \\
\hline John (2013) & & 2012.4 & & & 178 \\
\hline Forestry Bureau & & 2014 & & & 216 \\
\hline Website & & 2015.10 .22 & & & 125 \\
\hline Longbao NNR & & 2016 & & & 216 \\
\hline
\end{tabular}

We investigated and collected the number of BNCs in the Longbao NNR over the past 40 years (Table 1). Yao (1982) observed 24 BNCs in Longbao in June 1978. The average density of BNCs in June 1978 and May to June 1979 was $0.78 / \mathrm{km}^{2}$ and $0.76 / \mathrm{km}^{2}$, respectively. They observed that the BNCs nested in swampy areas that were not normally accessible to humans or domestic animals. Nests were often built 
on grass with weeds and dry grass or built on soil islands with higher ground above the water surface. The work by Yao represents the earliest record about the number of BNCs in the Longbao area. Li and Zhou (1985) observed 29 BNCs (24 adult and 5 chicks) in Longbao from mid-July to early August 1984, among which only 7 adult birds participated in breeding. Some scholars (Li 2002) recorded 108 BNCs in Longbao in July 1998. Farrington et al. (2013) observed the number and location of BNCs in 2011 and 2012. In April 2011, when BNCs had just arrived, the largest number of BNCs observed by Farrington was 216 , and they were mainly distributed around the lake and the meadow area of the western south. Then, some unnested BNCs moved away, and other BNCs began to build their nests on Longbao Beach. The total number of birds remained between 100 and 150. A total of 178 BNCs were observed on April 20, 2012, and 128 adult BNCs had bred and roosted here by June 30 . The remaining BNC data were mainly provided by the local forestry bureau and Longbao NNR. In 2016, the news reported that the Longbao NNR achieved remarkable results in bird protection. The number of bird population resources has increased annually, from the initial 61 species to 84 species at present. The number of BNCs increased from 22 in 1984 to 117 in 1992, 158 in 2002, and 216 in 2016.

\section{Nest site characteristics}

The 21 BNC nests observed by Farrington (2013) were located in marsh meadows, lake islands and alpine meadows. The elevation of the 21 nest locations ranged from 4205 to $4213 \mathrm{~m}$. The nearest distance between nests in different microhabitats varied between 200 and $1000 \mathrm{~m}$ in marsh meadows, 200-300 $\mathrm{m}$ in lake islands and $400-800 \mathrm{~m}$ in alpine meadows. The nearest distance from the nest to the road was $400-2500 \mathrm{~m}$, and the nearest distance to the water surface was no less than $800 \mathrm{~m}$. The disturbance degrees ranging from strong to weak were alpine meadows, marsh meadows and lake islands.

We observed 9 BNC nests with 5 island nests and 4 grass nests by telescope on May $30^{\text {th }}$ and $31^{\text {st }}, 2018$. Three grass nests were located in the same place as in 2011. The main nest was located in the mainland of the wetland. Some nests were located in a slightly dry area in the eastern region. Island nests were distributed on islands in open waters or islands with star-like distributions. The typical features of the island nests were that they were well concealed and less disturbed nests occurred where people and animals could not easily approach. Several island nests were almost entirely round and 2-20 m from the water surface. BNCs prefer to nest on isolated islands surrounded by water. If the water level rose too much, the island nest would be submerged. This nest location is similar to the nest location in the northern Tibetan region observed by Kuang et al. (2010). The sixth island nest was black with a large radius and was slightly higher than the surrounding ground (Fig. 4). Grass nests were made with rich deposits in dry or lodging plants, were located in drier areas and had a stable shape for reuse (Fig. 5).

Nests located in the northwest of the wetland were distributed on both sides of the lake, and the nearest distances between them were maintained at 200-500 m. The nearest nest distances in the middle of the wetland were maintained at 300-1000 m. Nests in the eastern part of the wetland were distributed in the slightly dry meadows, with the nearest nest distances at 1000-2000 m. The distance between island nests 
was 180-550 m, and they were located near the open water; the distance between grass nests was 1000$1500 \mathrm{~m}$, and they were located farther from the open water. The nearest distance from nests to the highway was 300-800 meters.

\section{Land cover change}

The classification results of the Longbao nature reserve are shown in Fig. 6 and Fig.7. From 1988 to 2015, marsh meadows, bare land and lakes in Longbao NNR showed a decreasing trend (Fig. 8(a)); alpine meadows, alpine tundra and rivers showed an increasing trend; and artificial buildings, roads and houses showed an increasing trend. In particular, six new branch roads were added, which made the reserve more fragmented and disturbed the habitat of BNCs. The greatest loss in area was observed for marsh meadows, while the greatest increase in area was observed for alpine tundra. The average temperatures increased from 1978-2016, which melted the mountain snow and permafrost and washed away the mountains, thus leading to an increase in river area and widening of riverbeds. The image classification results on the west side of the reserve showed that the upper water area was large with less vegetation in 1988 but small with more vegetation in 2015.

In the core area of BNC habitat(Fig. 8(b)), marsh meadows, alpine meadows and bare fields decreased; alpine tundra, houses and other artificial structures increased; and lakes remained stable. However, the number of marsh meadow patches in the core area increased mainly near the west outlet of the lake. Alpine tundra increased the most in the core area. In the buffer zone(Fig. 8(c)), alpine meadows increased the most and alpine tundra decreased the most. Marsh meadows, bare land, and lakes decreased, and rivers, roads, and buildings increased. The variation in the experimental area was consistent with that of the buffer zone. Bare land showed the maximum reduction in the $1 \mathrm{~km}$ buffer zone, while alpine meadows and buildings increased.

\section{Discussion}

\section{Increased in the number of BNCs}

The number of BNCs has increased slowly from 24 to 216 between 1978 and 2016, with an average rate of approximately 5 per year. In addition, we performed two measurement campaigns during migration on October 28th, 2010 (118), and October 22nd, 2015 (125). We divided the BNC data into four periods (Fig. 9). During the first ten years from 1978 to 1988, the number remained at no less than 30 and increased slowly, with an average rate of 0.4/year. In the second ten years from 1991 to 2000 , the population grew from approximately 60 to 120, and the average rate was about 6/year. From 2001-2010, the quantity remained stable at approximately 150 except in 2004. After 2011, the number increased slowly and remained stable at approximately 200 .

Statistical results showed that from 1960 to 1990, large-scale hunting of wild animals in the areas where BNCs were distributed caused a decline in the population of wild animals (including BNCs) in most areas of Asia (Li FS, 2014). With the establishment of the NNR in 1986, the number of BNCs exceeded 50 in 
1991 and increased rapidly to 117 in 1992 . This finding is closely related to China's accession to the Wetland Convention in 1992. The protection, restoration and reconstruction of wetlands entered a period of rapid development, including both summer breeding and wintering grounds (Farrington ad Zhang, 2013). From 2001 to 2010, the growth rate of BNCs was slow, and the largest number was 158 . Since 2010, 216 BNCs have migrated to the reserve. However, due to the limited bearing capacity of the reserve, the number of BNCs that can breed remains at approximately 150. In 2014 and 2016, the population of BNCs stabilized at 216. In 2014, due to the expansion of the highway through the wetland, a large number of construction personnel and machinery entered the construction site during the breeding period of the BNCs, which seriously interfered with the normal breeding of BNCs. There were only 6 pairs of BNCs nesting and laying eggs until the end of June (Li et al. 2014).

\section{Annual population changes in BNCs from April to November in Longbao}

Every year in late March or early April, groups of BNCs fly to Longbao from their wintering areas. In April, the population of BNCs was highest in this area. Some of the cranes occupied their territory and began to build nests, while others continued to migrate to other places as breeding habitats. As a result, the population of BNCs in the Longbao area tended to stabilize, and after nesting and breeding in May, the number of young cranes in June gradually increased and then decreased. Young cranes have to learn to find prey, fly and other skills before flying to their wintering areas within only a few months from birth to the end of October or early November. The final survival of the crane is small due to the impact of wild dogs, prairie vultures and other natural enemies. In the breeding period of July 2011, Farrington et al. (2013) observed a maximum of 43 young cranes and a minimum of 24 young cranes; however, only 7 young cranes flew back to Longbao in 2012. BNCs migrate to overwintering grounds in October; thus, the numbers gradually decrease. Therefore, the number of BNCs observed on October 28,2010 , and October 22, 2015, was less than that observed in other months.

\section{Nest site microhabitats}

A suitable nest site is the main factor affecting the reproductive success rate. According to the principal component analysis, two main principal components were extracted from six factors (Table 2). The variance contribution rate of the first component was $42 \%$, and it mainly represented the nearest distance between nests, with more than $70 \%$ occurring within $500 \mathrm{~m}$; the variance contribution rate of the second component was $27 \%$, and it mainly represented the nest microhabitat type, with $69 \%$ built in the swamp meadow. The main factors affecting the nesting location of BNCs in the Longbao wetland were the distance between adjacent nests and habitat type. Wu et al. found that factors associated with the

selection of nest sites in the Ruoergai wetland Nature Reserve included water body size, distance to water, water depth and the level of nest concealment (Wu et al. 2009). Kuang et al. (2010) discovered that the area and status of the island, safety, demand for building nests, and nest location in the island are the main nest characteristics. Nest site selection by BNCs in Yanchiwan National Nature Reserve was determined by the habitat type, disturbance and water depth (Zhang et al. 2017). 
Table 2

Results of the PCA for nest location factors in 2011

\begin{tabular}{|lll|}
\hline Variables & \multicolumn{2}{l|}{ Principal component } \\
\cline { 2 - 3 } & $\mathbf{1}$ & $\mathbf{2}$ \\
\hline Nest microhabitat type & -0.029 & 0.931 \\
\hline Elevation & 0.619 & 0.251 \\
\hline Distance to Road & 0.704 & -0.006 \\
\hline Disturbance & 0.695 & 0.494 \\
\hline Distance to water(m) & 0.599 & 0.677 \\
\hline Distance between adjacent nests $(\mathrm{m})$ & 0.901 & 0.054 \\
\hline \% of total variance & 42.224 & 27.220 \\
\hline \% of cumulative variance & 42.224 & 69.444 \\
\hline
\end{tabular}

\section{Analysis Of Land Cover Change In Protected Areas}

Although the population of BNCs has gradually increased and stabilized in the past 40 years, BNCs and their habitat are still facing severe challenges, including environmental change, human disturbance and climate fluctuation.

First, the classification results showed that the vegetation area in the Longbao reserve increased while the grassland area was degraded. The alpine meadow and alpine tundra increased obviously, and alpine meadow patches shifted gradually into larger patches; however, marsh wetlands degenerated into alpine meadows, and marsh meadow patches became fragmented. In particular, marsh meadows and alpine meadows were reduced in the core area of the reserve that BNCs depend on for survival, which directly reduced the foraging and habitat sources of BNCs. The lake area decreased slightly, which was mainly because the lake area on the east side of the reserve decreased and became dry. Many groups of nonbreeding BNCs prefer to stay here and take breaks during migration (Farrington and Zhang, 2013). The amount of bare land decreased and changed to alpine tundra and meadows, especially on the southeastern slopes of the reserve, which shows that the establishment of the NNR has effectively protected the land surface and topography. The amount of water transported from the mountain snowmelt increased, which caused erosion and widening of the river channel. We found that the river flow was not large based on the field observations at the end of May 2018, although almost all the fields beside the river were bare and a large number of yak and sheep were grazing in the area, thus leading to grassland degradation along the river bank.

Second, artificial buildings, including buildings and roads in the reserve, increased and BNCs faced more human interference. The main reason for the increase in buildings was that Longbao Town had expanded 
significantly in the past 30 years. Moreover, victims of the Yushu earthquake in 2010 were relocated along Zhiduo Road (in the southeast with magenta color of Fig. 7), and some herdsmen settled down along Zhiduo Road and on the south bank of the reserve. The increase in buildings led to more surrounding human activities, which had a certain impact on the roosting reproduction of BNCs. The increase in road area was mainly due to the restoration and widening of S308 from Zhiduo to Yushu after the 2010 earthquake as well as the construction of new branches within the reserve, especially in Longbao town and east of the reserve. Wu (1993) found that cultivated fields increased, and woodlands decreased, from 1992 to 2006 through Landsat images in the Huize Nature Reserve, which is the southernmost reserve for wintering BNCs in China. Scott (1993) also found that habitat loss and disturbance were the main threats to the species.

Third, egg collection, feral dogs and intense grazing pressure represented important threats by Scott (1993). The Longbao reserve is nearly surrounded by pasture, and multiple fences are constructed except in the open lake area at the center; thus, grazing is extremely serious. In addition, rodent damage is serious in the reserve, and rat holes are especially dense. High voltage towers and telephone poles have also been added to the reserve. The construction of artificial buildings has resulted in many surrounding grasslands becoming bare. We observed a Tibetan fox on the eastern branch road of the reserve and a wolf on the north side of the national highway of S308 in May. These animals are potential hazards to BNCs. Fences prevent livestock access to private grasslands, although BNCs are also affected by this policy change because they have to increase their search time by flying from one patch to another (Yang et al. 2007). Several roads and artificial establishments have been built near the wetland. Roads, buildings and large areas of fences have fragmented wetlands and meadows.

\section{Effects of climate change on the population of BNCs in Longbao}

Climate change is an important factor affecting the breeding of BNCs. The average temperature of the Yushu meteorological station showed a slow rising trend since 1978(Fig. 10). The average temperature remained at $4.56^{\circ} \mathrm{C}$ during the decade from 2001 to 2010 , which was $1.4^{\circ} \mathrm{C}$ higher than the average temperature from 1978 to 1988(Table 3), and then decreased slightly from 2011 to 2016. Rising temperatures lead to permafrost ablation and snow melting and affected the breeding and foraging of BNCs. There was no significant change in precipitation from 1978 to 2016(Fig. 11). Precipitation showed a slow decreasing trend from 1978 to 1988 and the average precipitation was close to $500 \mathrm{~mm}$ (Table 3). From 1991 to 2000 and 2001 to 2010, precipitation basically remained at approximately $470 \mathrm{~mm}$. From 2011 to 2016, the precipitation increased rapidly while the temperature also decreased. 
Table 3

Change in meteorological factors at Yushu station every decade from

1978-2016

\begin{tabular}{|lll|}
\hline Year & Average temperature $\left({ }^{\circ} \mathrm{C}\right)$ & Average precipitation $(\mathrm{mm})$ \\
\hline $1978-1988$ & 3.16 & 493.2 \\
\hline $1991-2000$ & 3.45 & 473.52 \\
\hline $2001-2010$ & 4.56 & 472.27 \\
\hline $2011-2016$ & 3.66 & 509.8 \\
\hline
\end{tabular}

\section{Conclusions}

The number of BNCs increased from 24 in 1978 to 216 in 2016, thereby showing a slow growth trend and tending to be stable. The establishment of the Longbao NNR has been a powerful measure to protect BNCs since 1986. BNCs in the Longbao wetland prefer to nest in swampy wetlands or on islands with open water or star-like distributions. The nesting site of BNCs in the Longbao wetland was closely related to the nearest distance between nests and habitat type during the six microhabitat factors.

Although the number of BNCs has grown and stabilized over the past 40 years, cranes and their habitats still face serious challenges. From 1988 to 2015, the classification results of remote sensing images showed that the marsh wetland on which BNCs live decreased and the artificial buildings, including roads and houses, increased, which affected the habitat of BNCs. The fragile plateau wetlands showed exacerbated degradation, and the connectivity of the wetland was reduced. In addition, grassland grazing and rodent damage are serious and encroach upon and destroy the grassland. Besides, the rising average temperature and precipitation over the past 40 years have also had an impact on the number of BNCs.

The carrying capacity of longbao NNR is limited. We suggest reducing grazing, removing fences and protecting wetlands to achieve a stable ecological balance. Conservation efforts should focus on the protection of existing lakes, minimizing disturbance impacts and maintaining small patches of swamp areas as important buffer zones.

\section{Declarations}

\section{Acknowledgments}

We thank the Qinghai Provincial Environmental Protection Department, Forestry Department and Longbao NNR for providing valuable data on BNCs. We thank the China Meteorological Administration for providing the meteorological data.

\section{Funding}


This research was funded by the National Key R\&D Program of China (Grant No. 2018YFC0809400) undertaken by Chou Xie, the National Natural Science Foundation of China (Grant No. 41431174) undertaken by Yun Shao, the Science and Technology project of State Grid (Grant No. GCB17201700142) undertaken by Chou Xie, and the National Natural Science Foundation of China (Grant No. 41571328) undertaken by Chou Xie.

\section{Conflicts of interest/Competing interests}

The researcher claims no conflicts of interests.

\section{Ethics approval}

Not applicable.

\section{Consent to participate}

Not applicable.

\section{Consent for publication}

Not applicable.

\section{Availability of data and material}

The Landsat image can be down load from https://earthexplorer.usgs.gov/. Yushu weather station data can be downloaded from the China Meteorological data service center and the website is http://data.cma.cn/site/index.html. The other datasets used and/or analysed during the current study are available from the corresponding author on reasonable request.

\section{Code availability}

Not applicable.

\section{Authors' contributions}

Author contributions: Qiufang Wei, Yun Shao and Chou Xie designed the study and analysis. Baoshan Cui and Brian Brisco put forward guidance and revision opinions to the paper. Bangsen Tian and Kun Li participated in data collection and processing. Wenjia Tang observed the location of the nests. All authors contributed substantially to the data processing, writing and discussion of the paper.

\section{References}

1. BirdLife International (2017) Grus nigricollis (amended version of 2016 assessment). The IUCN Red List of Threatened Species 2017: e.T22692162A110659467. 
2. Bishop MA (1996) Black-necked Crane (Grus nigricollis). In C. D. Meine and G. W. Archibald, eds. The cranes: status survey and conservation action plan. Gland \& Cambridge UK: IUCN/SSC Crane Specialist Group. Online version: Jamestown: USGS Northern Prairie Wildlife Research Center, March 2, 1998. http://www.npwrc.usgs.gov/resource/birds/cranes/index.htm; downloaded on 21 August 2012.

3. Bishop MA, Tsamchu D (2007) Tibet Autonomous Region January 2007 Survey for Black-necked Crane, Common Crane, and Bar-Headed Goose. China Crane News, 11:24-26.

4. Bock C E (1997) The role of ornithology in conservation of the American West. Condor 99: 1-6.

5. Cangjue ZM, Yang L, Li JC, Yangjin ZG (2008) Current status of conservation and research on Blacknecked cranes in Tibet. SiChuan Journal of Zoology 27(3): 449-453.

6. Caughley G (1994) Directions in conservation biology. Journal of Animal Ecology 63: 215-244.

7. Dwyer NC, Bishop MA, Harkness JS, Zhang YZ(1992) Black-necked cranes nesting in Tibet autonomous region, China. Proceedings of the Sixth North American Crane Workshop, ed. D.W. Stahlecker, Grand Isl: North American Crane Working Group. 75-80.

8. Farrington JD and Zhang XL (2013) The Black-necked Cranes of the Longbao National Nature Reserve, Qinghai, China Current Status and Conservation Issues. Mountain Research and Development. 33(3): 305-313.

9. Farrington JD, Zhang XL, Zhang M (2013) The birds of the Longbao National Nature Reserve and surrounding basin, Yushu county, Qinghai, China. Forktail 29:57-63.

10. Guo JT (1981) Ecological problems about black-necked Crane. Chinese Journal of Wildlife 4:35-38.

11. Harris J, Mirande C(2013) A global overview of cranes: status, threats and conservation priorities. Avian Research 4(3): 189-209.

12. Kuang FL,Zhuoma C, Li JC, Yang L, Liu N (2010) Nest site characteristics and foraging habitat selection of breeding black-necked cranes in bange, Tibet Autonomous Region, China. Journal of Northeast Forestry University 11:89-92

13. Li DH, Zhou ZJ (1985) Behaviors of Black-necked Cranes during nursing period at Long Baotan. Chinese Journal of Wildlife, 6:4-9.

14. Li FS. (2014) IUCN Black-necked Crane (Grus nigricollis) conservation plan. Zoological research 35(S1): 3-9.

15. Li FS, Bishop MA (1999) Ecology and conservation of Blacknecked Cranes (Grus nigricollis). In: dams NJ, Slotow RH(eds) Proceedings of the XXII International Ornithological Congress, Durban, South Africa. Birdlife South Africa, Johannesburg, 2533-2543.

16. Li JR, Cao J, Yang F (2014) Research, ecological distribution and conservation status of Blacknecked cranes in Qinghai Province.Zoological Studies. 35(S1): 76-79.

17. Liu Q, Wang K, Li FS, Kong DJ, Yang XJ (2014) Numbers and distribution of Black-necked Cranes (Grus nigricollis)at Ruoergai Wetland on the Eastern Qinghai-Tibet Plateau. Zoological Research 35(S1): 134-138. 
18. Li XM (2002) Cranes in China. The 5th National Symposium on Biodiversity Conservation and Sustainable Use. Hangzhou, Zhejiang, China.

19. Lin Zhi (2006) Longbao Lake: the hometown of black-necked crane. China's tu nationality 03:37-39.

20. Li ZM, Li FS (2005) Research on the Black-necked Crane [in Chinese with English preface and abstract]. Shanghai, China: Shanghai Science, Technology, and Education Press.

21. Lü ZB, Yao JC, Liao YF (1980) The observation on Black-necked Cranes breeding ecology. Chinese Journal of Zoology, 1:19-24.

22. Ma ZT, Li FX, Li P区Xiao JS (2009) Study on ecological environment dynamic change in Yushu Longbao, Qinghai. Pratacultural Science, 26(7): 6-11.

23. Scott DA (1993) The black-necked cranes grus nigricollis of Ruoergai marshes, Sichuan, China. Bird Conservation International, 1993. 3(3): p. 245-259.

24. Song HT, Zhang YS, Gao HF, Guo YH, Li SN (2014) Plateau wetlands, an indispensible habitat for the black-necked crane (Grus nigricollis) - A Review. Wetlands 34(4): 629-639.

25. Wang YH, Chen EL (2002) The black-necked cranes in China. Guiyang: Guizhou Renming Publishing House.

26. Wang YH, Wu ZK, Li ZM, Li DH, Li LX (1991) An observation on the nests, eggs and chicks of Blacknecked Crane. Acta Biologica Plateau Sinica, 10:117-124.

27. Willson M F, Gende S M (2000) Nesting success of forest birds in southeast Alaska and adjacent Canada. Condor 102:314-324.

28. Wu HQ, Zha K, Zhang M, Yang XJ (2009) Nest site selection by black-necked crane grus nigricollis in the Ruoergai wetland, China. Bird conservation international 19(3): 277-286.

29. Wu ZL, Zhang KX, Li WJ, Jiang P (2013) Number, habitats, and roosting sites of wintering blacknecked cranes in Huize nature reserve, Yunnan, China. Mountain research and development, 33(3): 314-322.

30. Yao JC (1982) The quantity distribution of Black-necked Cranes in Qinghai province. Chinese Journal of Wildlife 1: 20-22.

31. Zhang JJ, Luo J (1991) Number and distribution of black-necked crane on Ruoergai Plateau Marsh. Sichuan Journal of Zoology 3: 37-38.

32. Zhang LX, An B, Shu ML, Yang XJ (2017) Nest-site selection, reproductive ecology and shifts within core-use areas of Black-necked Cranes at the northern limit of the Tibetan Plateau. PeerJ 5:e2939; DOI 10.7717/peerj.2939.

\section{Figures}




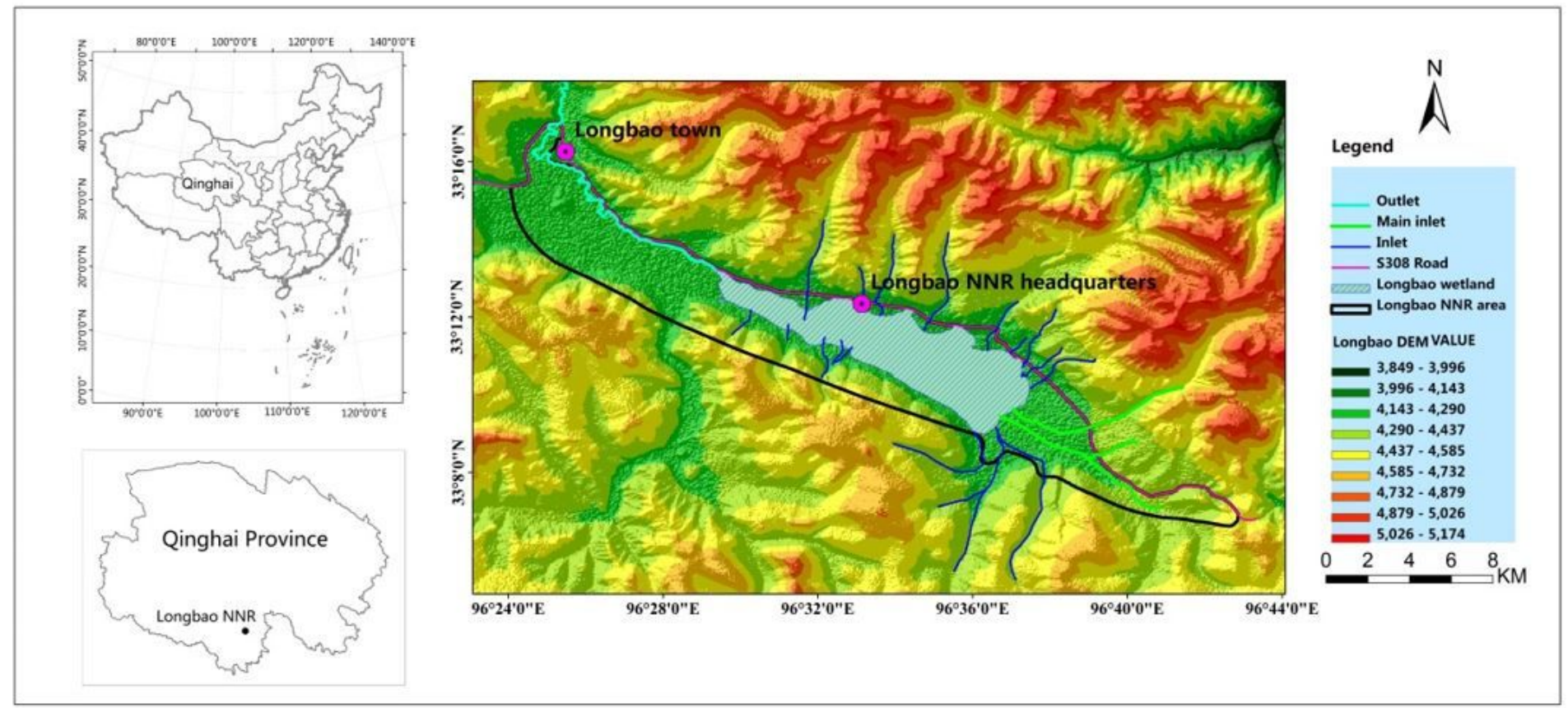

\section{Figure 1}

Location of the study area Note: The designations employed and the presentation of the material on this map do not imply the expression of any opinion whatsoever on the part of Research Square concerning the legal status of any country, territory, city or area or of its authorities, or concerning the delimitation of its frontiers or boundaries. This map has been provided by the authors.

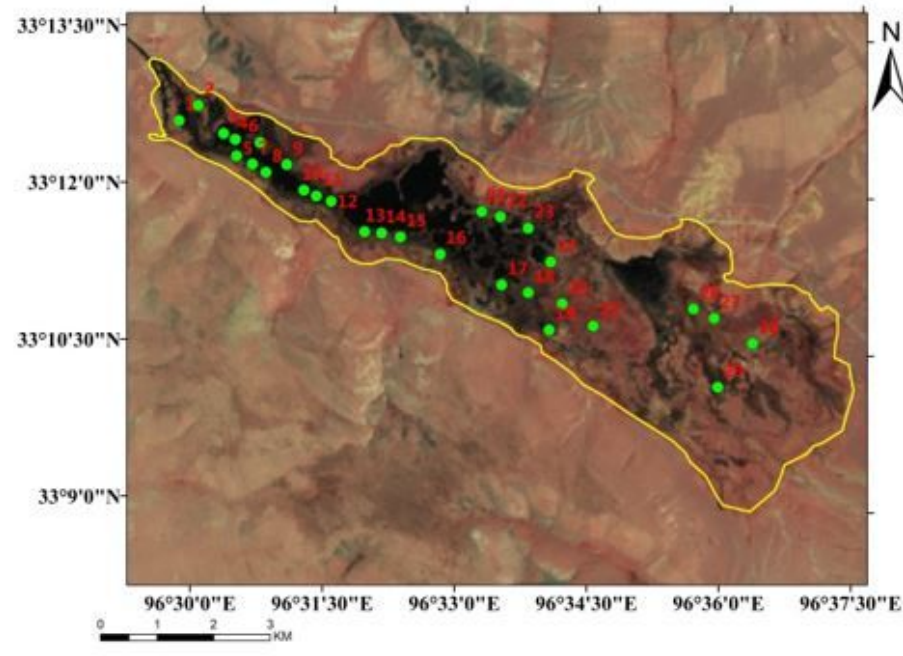

(a)

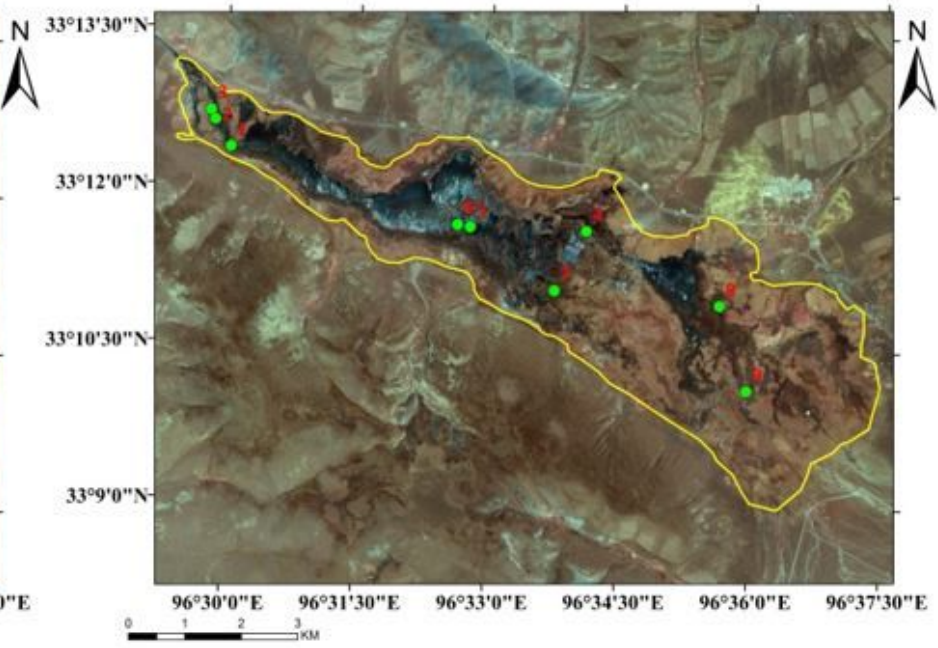

(b)

\section{Figure 2}

Nesting sites observed in 2011 and 2018 ((a) Location of 29 known BNC nests on the main Longbao wetland in the spring of 2011 by Farrington (Image source: Landsat-5, Date: 20110527). (b) Nesting sites 
we observed in the spring of 2018 (image source: GF-1, date: 20180515) Note: The designations employed and the presentation of the material on this map do not imply the expression of any opinion whatsoever on the part of Research Square concerning the legal status of any country, territory, city or area or of its authorities, or concerning the delimitation of its frontiers or boundaries. This map has been provided by the authors.

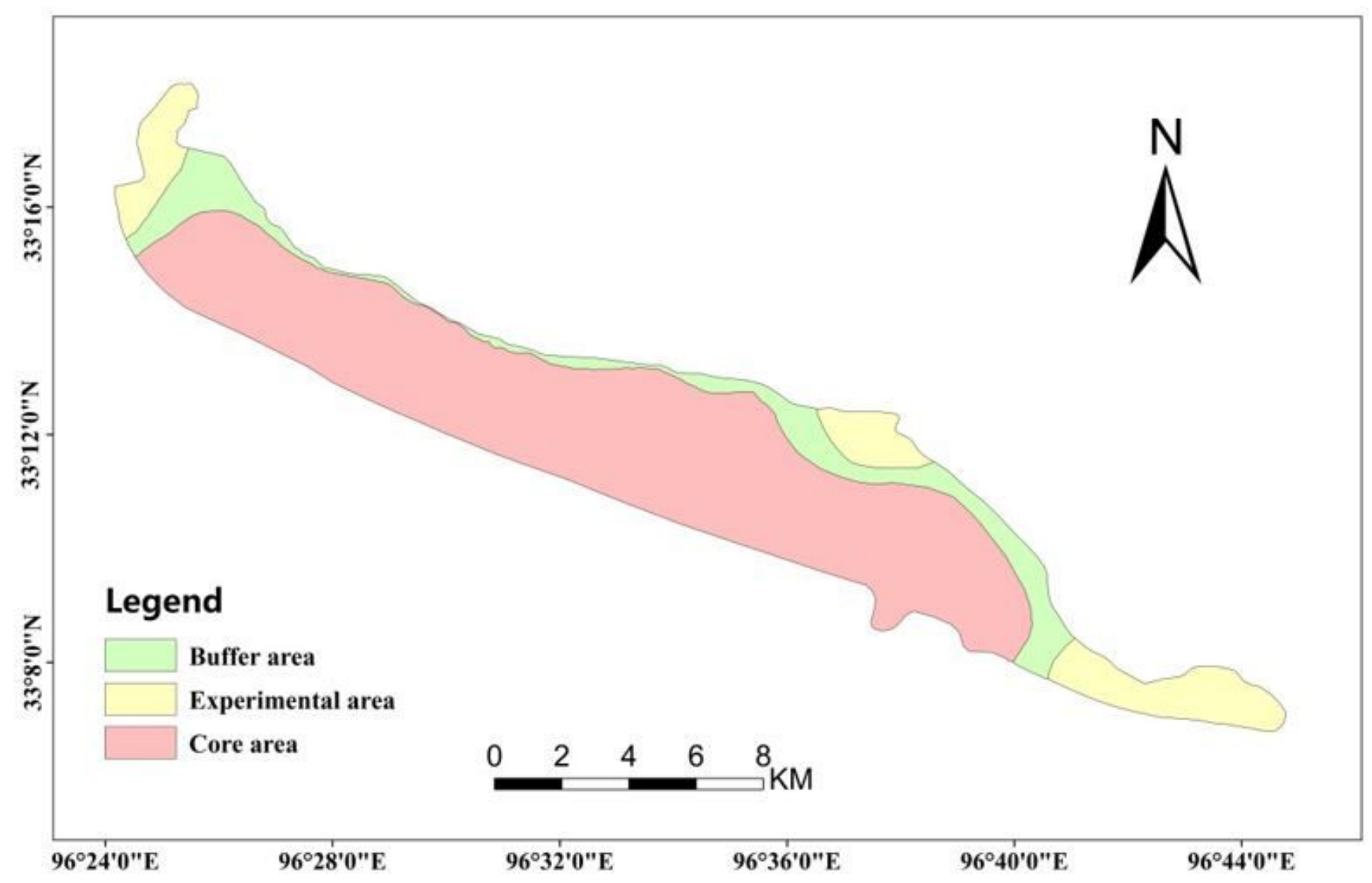

\section{Figure 3}

Functional zoning of Longbao NNR. Note: The designations employed and the presentation of the material on this map do not imply the expression of any opinion whatsoever on the part of Research Square concerning the legal status of any country, territory, city or area or of its authorities, or concerning the delimitation of its frontiers or boundaries. This map has been provided by the authors. 


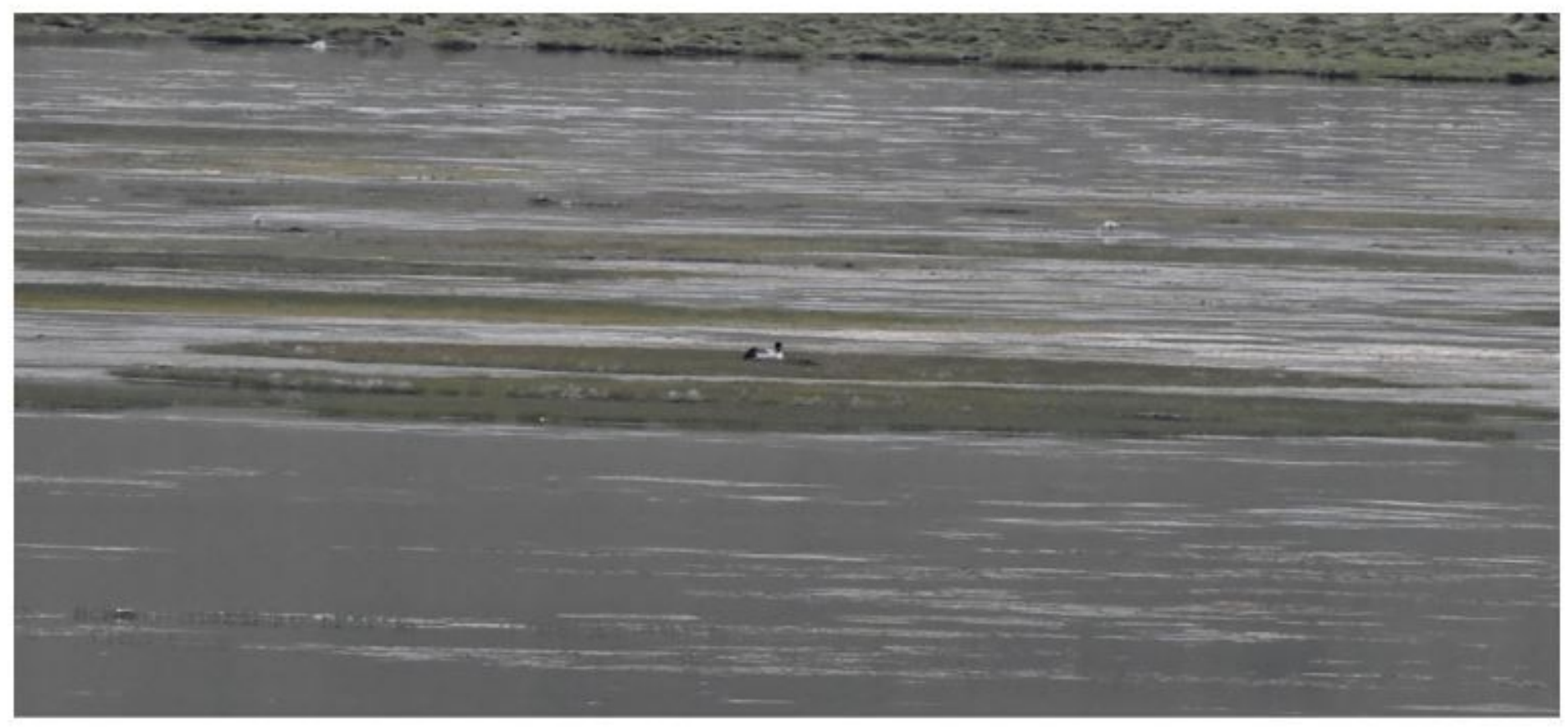

Figure 4

Island nest observed in May 2018

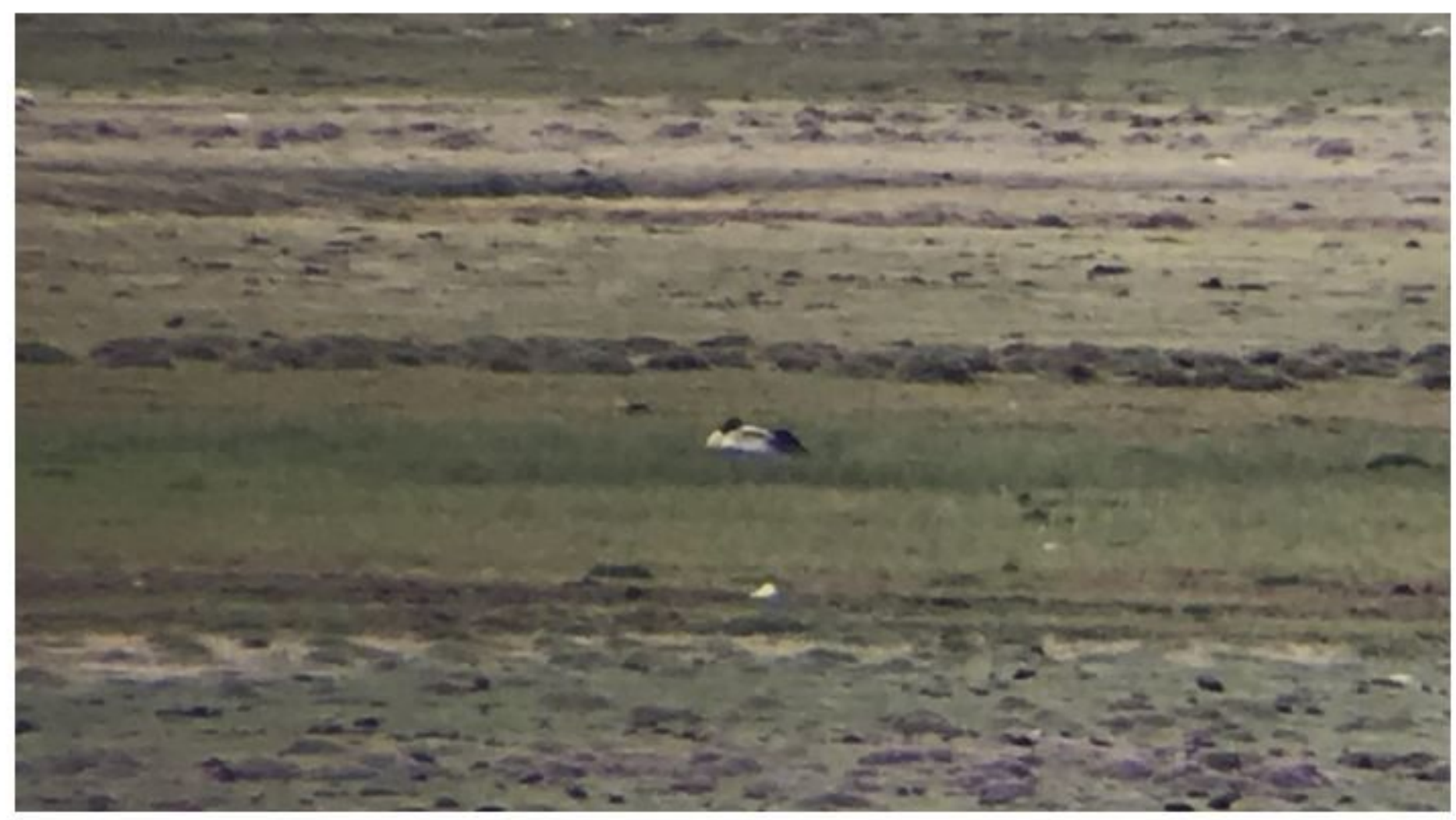

Figure 5

Grass nest observed in May 2018 


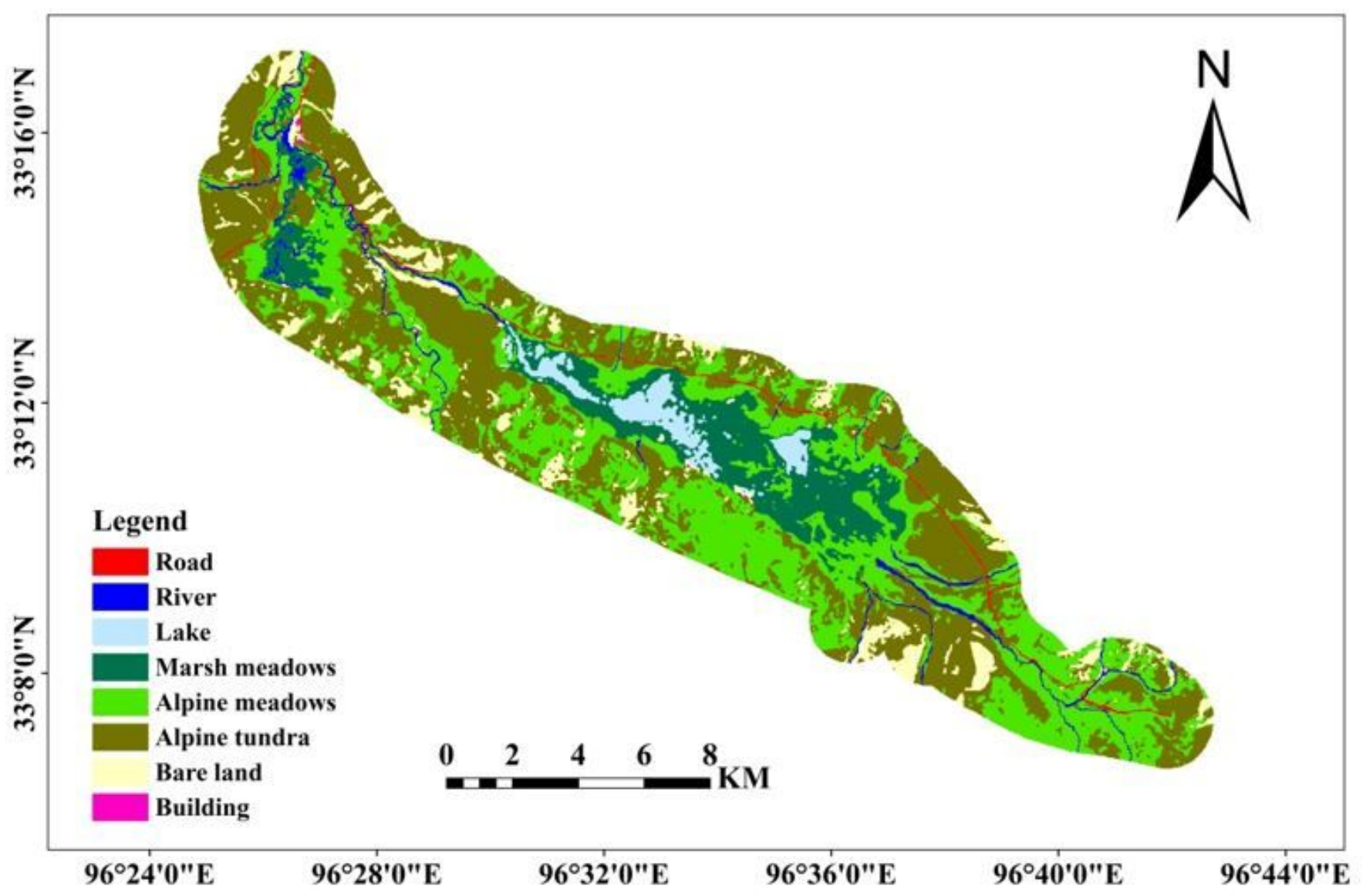

Figure 6

Classification result of the Longbao nature reserve (boundary buffer of $1 \mathrm{~km}$ ) on August 15, 1988. Note: The designations employed and the presentation of the material on this map do not imply the expression of any opinion whatsoever on the part of Research Square concerning the legal status of any country, territory, city or area or of its authorities, or concerning the delimitation of its frontiers or boundaries. This map has been provided by the authors. 


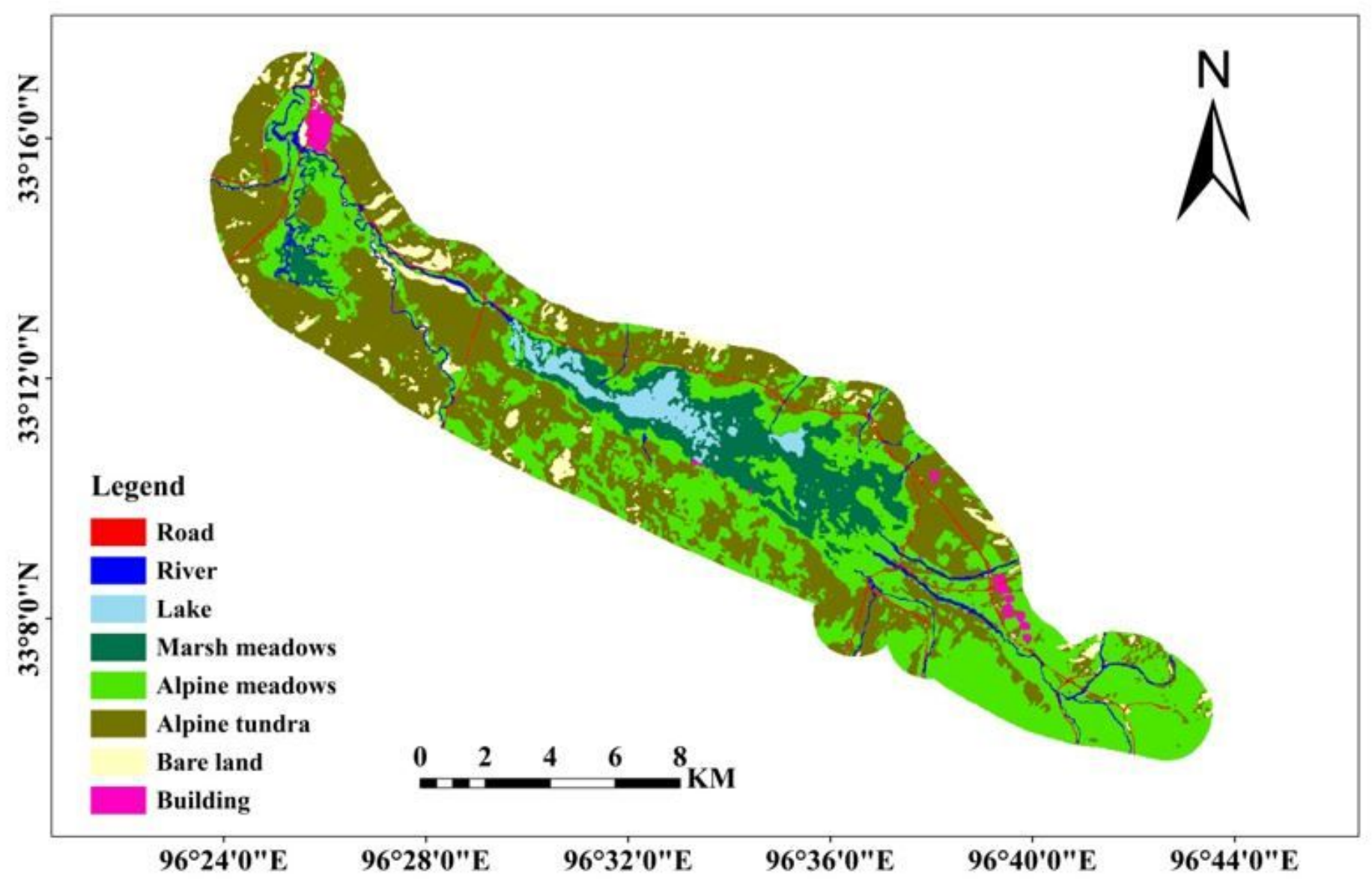

Figure 7

Classification result of the Longbao nature reserve (boundary buffer of $1 \mathrm{~km}$ ) on July 25, 2015. Note: The designations employed and the presentation of the material on this map do not imply the expression of any opinion whatsoever on the part of Research Square concerning the legal status of any country, territory, city or area or of its authorities, or concerning the delimitation of its frontiers or boundaries. This map has been provided by the authors. 

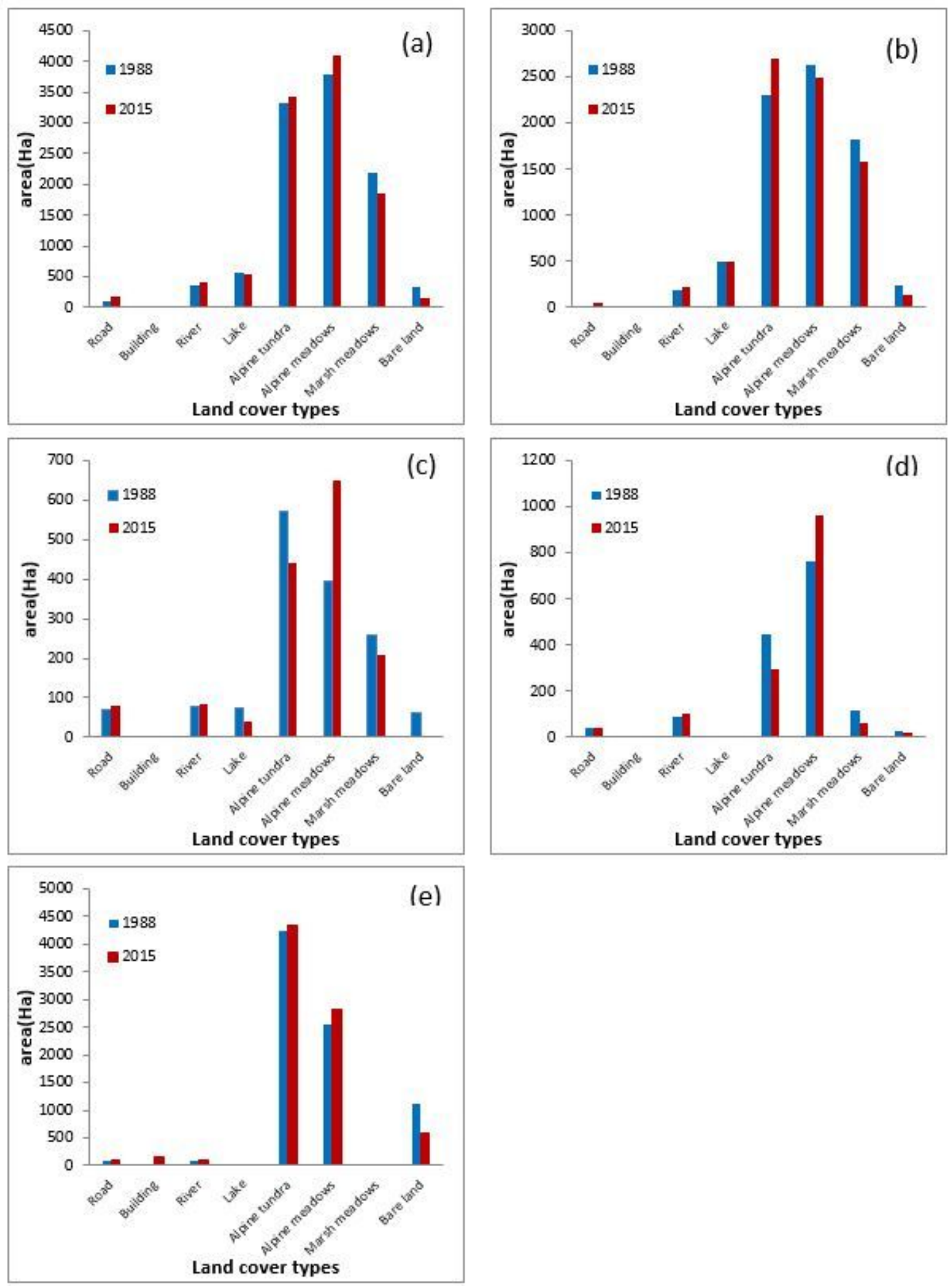

Figure 8

Classification results of protected areas and surrounding areas (unit: $\mathrm{Ha})((\mathrm{a})$ Protected area; (b) Core area; (c)Buffer area;(d) Experimental area;(e)1 km buffer area) 


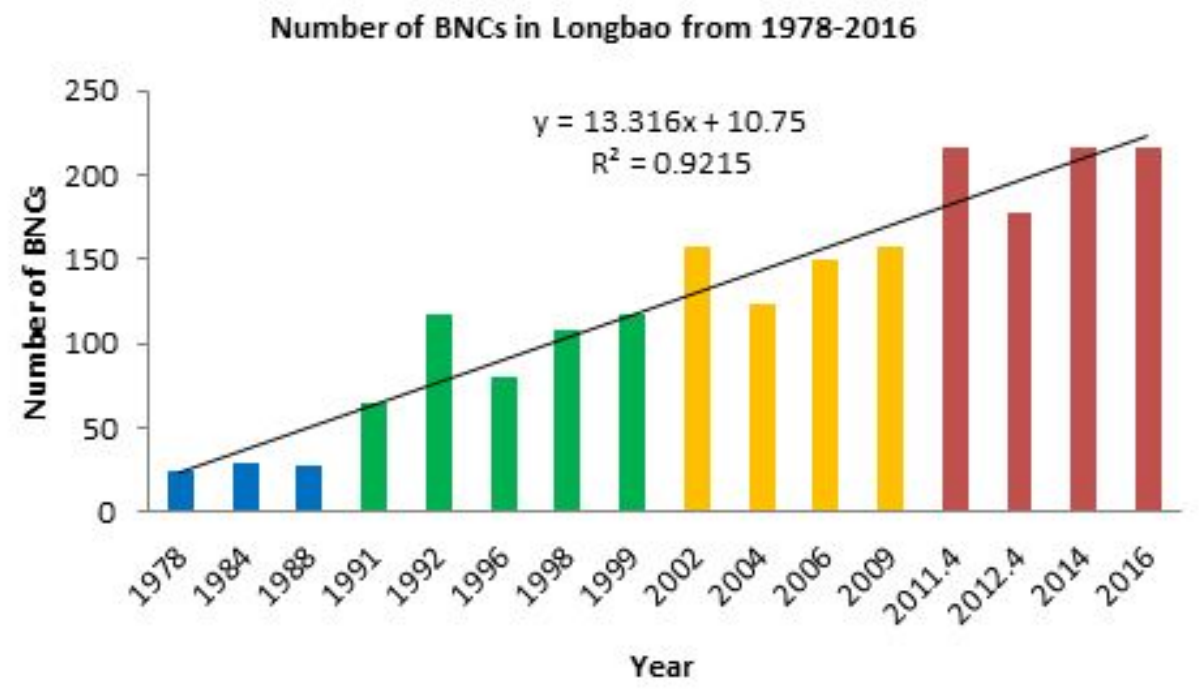

Figure 9

Number of BNCs in Longbao from 1978-2016

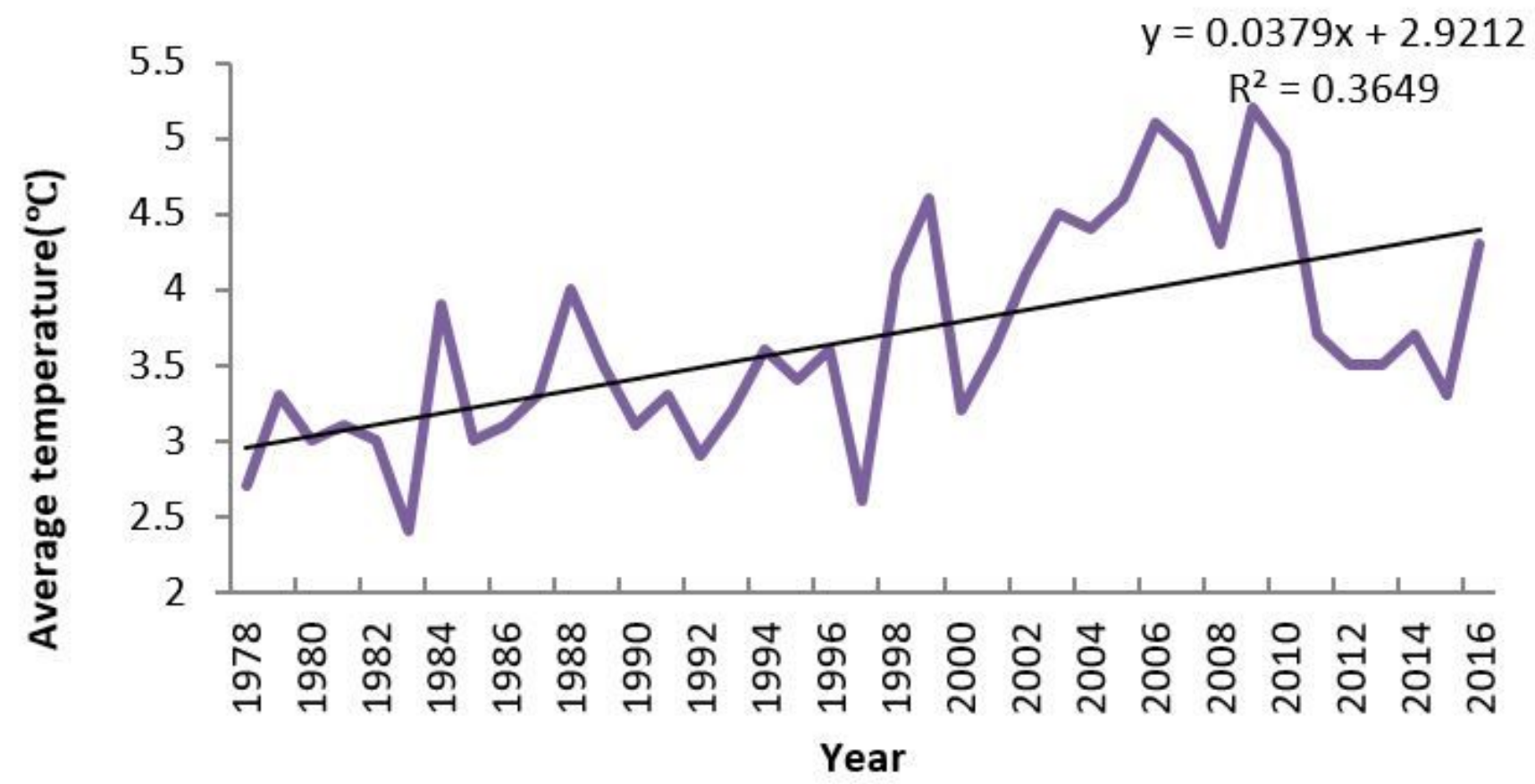

-average temperature L Linear of average temperature

Figure 10

Average temperature at Yushu weather station from 1978-2016 


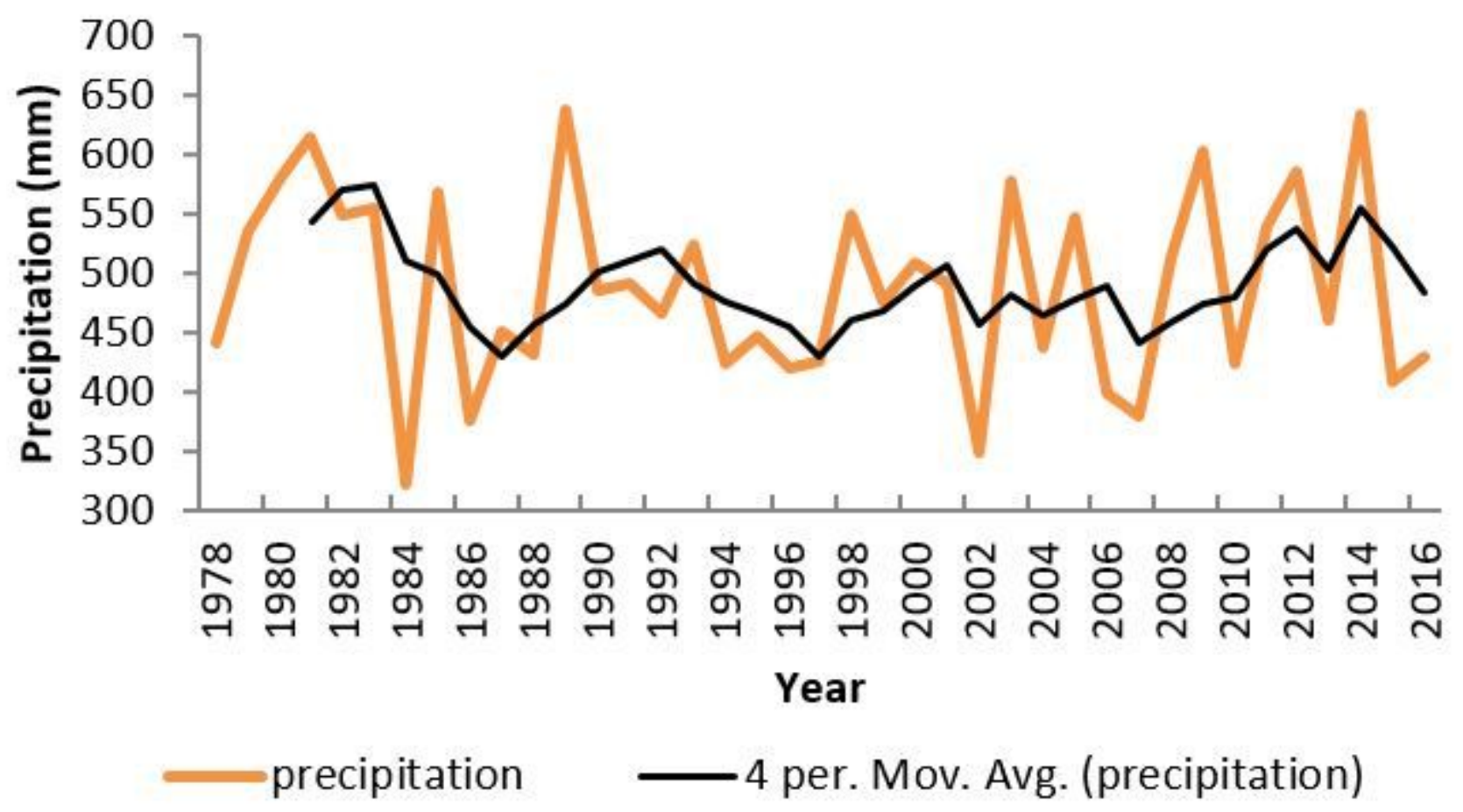

Figure 11

Precipitation at Yushu weather station from 1978-2016 